\title{
Section:
}

\section{HISTORY AND MODERNITY}

\section{THE DISMISSAL OF MYKHAILO DRAHOMANOV FROM THE UNIVERSITY OF ST. VOLODYMYR: TEXT, SUBTEXT, CONTEXT}

\author{
ROMAN PIKHMANETS
}

\begin{abstract}
The article discusses the motives and circumstances surrounding the dismissal of Mykhailo Drahomanov from Kyiv University. There is an emphasis on the interdependence of this episode and the Ems Ukaz,, its connection with Drahomanov's Ukrainophile campaign, his previous plans and intentions regarding an overseas publication. The author provides clarifications and corrections of the commonly held perceptions of the above-mentioned events.
\end{abstract}

Keywords: Ukrainophilia, Ems Ukaz, South-West Department of the Russian Geographical Society, overseas publication, Russification, provocations, insinuations.

\section{INTRODUCTION}

The dismissal of Mykhailo Drahomanov from Kyiv University seems well-known: a conflict with reactionary conservative circles and a ministry, involvement in Ukrainophile campaigns... However, like any canonical story, this one also contains "blank pages", omissions and understatements; this requires guesswork and the reassessment of certain aspects in order to form a coherent whole. For instance, this banishment and the Ems Ukaz are closely intertwined; to a certain extent, they even complement and determine each other. Thus the above-mentioned decree is worthy of observation at least in passing. Moreover, Drahomanov's direct influence on the appearance of the shameful document is normally left untouched.

According to the Avtobiograficheskaya Zametka (An Authobiographical Note), it all began when Dmytro Tolstoi, the minister of education, was inspecting an academic district in Kyiv; his supporters organized a lavish banquet for him, with toast speeches and gourmet treats. Subsequently the event was described in the Kievlianin newspaper (The Kyivan). The chief editor of the newspaper, Vitalii Shulgin, also did his bit by complementing the article with laudations and flatteries; the Moskovskie Vedomosti (Moscow News) wrote about the infallibility and vivifying power of Count Tolstoi's pedagogical system, which was sometimes unjustly criticized by certain social groups creating an artificial hysteria. Mykhailo Drahomanov was not just indignant at such deception - he called it "an extremely maladroit comedy, with Kyivan serfs burning incense to Minister Tolstoi**" $[4$, p. 51]. In the article under the headline Po povody kievskikh zastolnykh rechei (On Kievan Toast Speeches) published in Issue 12 of the 1873 Vestnik Yevropy (Herald of Europe), Drahomanov castigated the farce; this, of course, could not go unnoticed by

\footnotetext{
${ }^{*}$ Transl. note: $u k a z$ is a transliteration of the Russian for edict.

${ }^{* *}$ Henceforth the translation does not create the textual effect of the source language; its only aim being to render the semantic content of the original.
} 
the reactionary circles of Kyiv or the odious editor of the Kievlianin or Count Dmytro Tolstoi himself. "At first, they were uncomfortable attacking me personally, but then they began to attack the Kyiv Geographical Society, whose active member I used to be. This society came to be called a Ukrainophile bedlam, which under the guise of research promotes political separatism," Drahomanov recounted his memories later [3, 1, p. 60].

Persecutions became more systematic in 1874, when repressions were also launched against the revolutionary populists referred to as the narodnyky. In addition to being slandered and calumniated, Mykhailo Drahomanov "was becoming more and more aware of administrative claws" [3, 1, p. 61]. Once he was called on the carpet by his supervisor to discuss the content of a stinky letter, which accused him of presenting an introductory lecture from a socialist perspective (this Judas obviously "mistook the word sociology for socialism"). In addition, he was banned from giving public lectures about primitive cultures. On top of that, in the May of 1875, at the end of the semester, he received a pressing request, or rather a recommendation, to resign of his own accord, thus retaining the right to teach at the other universities of the Russian Empire. The supervisor of the Kyivan academic district, major general Platon Antonovych, who himself had been expelled from Moscow University (and exiled to the Caucasus) for membership in a secret society, was regarded as a smart and liberal person. Being skeptical about all the gossip and absurdities flying around Drahomanov, as well as the accusations brought against him, he decided to keep the problem shelved until it reached the monarch. The minister of education and his circle continued to calumniate Drahomanov. This time they received a telegram from the Halychian Moscowphiles who claimed that Drahomanov had been promoting separatism at a meeting in Halych. More specifically, Drahomanov was alleged to have suggested that Halych secede from its motherland, the Russian Empire, and go on to join Poland. Professor Hohotskyi, the addressee of the telegram, forwarded it to the ministry, and from there it was passed along to the tsar. Consequently, Drahomanov was declared an ardent separatist. He received another few letters urging him to resign - all to no avail (resigning would have meant "accepting all the accusations, absurd and unfair"). Eventually he was dismissed with cause "pursuant to Item 3, which equaled a ban from all kinds of civil service" [3, 1, p.62].

Holding a grudge against Drahomanov, Count Dmytro Tolstoi intended to set the whole of Petersburgh court against him since the publication of his study Vostochnaya politika Germanii i obrusenie (The Eastern Policy of Germany and Russification), which severely criticized the "Tolstovian classical system" [see: 7, p.31]. Moreover, Drahomanov regarded the minister of education's policy as "reactionarily aristocratic" because, among other things, it "was meant to delay the spread of elementary public schools" [3, 1, p.59].

\section{ANALYSIS AND DiscUSSION}

Mykhailo Drahomanov described the circumstances surrounding his dismissal in a compendium of memoirs. Though the overall picture is truthful, he withheld certain essential facts such as his own provocative role in this story, which had deplorable consequences not only for him personally but also for the Ukrainian nation as a whole. Recounting the events that occurred closer to the culminating episode, for instance in the brochure Narodni shkoly $v$ Ukrainini sered zhyttia i pysmenstva $v$ Rosii (Public Schools in Ukraine Amid the Life and Literacy in Russia), he openly admitted that the conflict itself had been triggered by his campaign against "toast speeches": "So for a sin committed by the one who stopped Citizen Tolstoi's serfs from lying beautifully the liars paid back the whole of Ukraine! Now it is not only at a school, a school library, but everywhere across Ukraine that liars have knifed the Ukrainian printed word!" [4, p.54]*.

Therefore, the historical plotline has another compositional element - the rising action. Taisiia Mykhalchuk recounts her memories of the initial stages of the conflict, when the Kievlianin newspaper

\footnotetext{
" That being said, the idea of Drahomanov's "sin" against Ukraine for the notorious Ems Ukaz receives two mentions in the brochure. "Whatever else could they fasten on to but our Ukrainian identity. Ukraine had to pay for our sins!" he admitted a little further down the text [4, p.51].
} 
Vitalii Shulgin condemned "a young scholar" who went on an overseas field trip "for the public money" and upon return found himself "in full opposition to the government that had sent him there". His behavior throughout the trip was meant to provoke and irritate not only official representatives but also law-abiding members of the public. Though the article did not mention Drahomanov's name, he could not ignore the criticism; so he started an argument in the opposing press such as Kievskii Telegraf (Kyivan Telegraph) and Sankt-Peterburgskie Novosti (St. Petersburgh News). "Of course, he responded with his characteristic hot-temperedness" [12, p.86].

Shortly afterwards, the conflict continued to escalate, fueled by the story with the minister of education, Count Dmytro Tolstoi, described above. His emotional and psychological state was aggravated by the delay in appointing him a full-time associate professor.

On the eve of his field trip, the university board appointed him a full-time associate professor at the World History Department. The confirmation of appointment was sent to the supervisor on October 12, 1870. The circumstances seemed favourable for Mykhailo Drahomanov: the document came to the academic district when the supervisor was sick, so the papers for St. Petersburgh were sent by his assistant, Mykhailo Tulov, "a person close to the Ukrainian movement" [10, p.381]. However, they remembered that in 1866 Prince Oleksandr Shyrynskyi-Shykhmatov, a well-known reactionary and sworn enemy of the national movement, informed on Drahomanov's connection with the party of Ukrainophiles. Consequently, the ministry authorized the supervising body to resolve the issue themselves - "on the personal responsibility of the district administration" [1, p. 95]. In view of the above, as well-as the candidate's outrageous behavior and scandalous publications, Platon Antonovych postponed the decision till Drahomanov returned from the overseas field trip. When it happened (September 1, 1873), Count Tolstoi was in Kyiv on a two-month visit doing some inspection. Antonovych "was an honest person" [7, p. 31] and sensible, but still he preferred to wait till the minister finished his inspection of the academic district. According to Drahomanov, his fear was "lest I should do anything unpleasant to Count Tolstoi during the introductory lecture or reception" [3, 1 , p.59]. As soon as the minister left, Mykhailo Drahomanov's appointment was confirmed, and it almost coincided with the incident at the farewell banquet.

This resulted in dirty insinuations and undisguised denunciations against Ukrainian identity in general - the banishment and persecution of its leaders, the closure of South-West Department of the Russian Geographical Society and (to crown the whole anti-Ukrainian campaign) the notorious Ems Ukaz banning the Ukrainian press, media, theater, songs. "Everything was banned," a witness summarizes. "Professor Vitalii Shulgin and his associates knew where to strike a blow. They took long to find the right moment; having nothing to find fault with, they took advantage of this situation (Drahomanov's speech) to achieve the desired" [12, p.86].

A similar opinion is expressed by Drahomanov's another contemporary - Oleksandr Kistiakivskyi. He explicitly reproached Mykhailo Drahomanov for "choosing to act in a manner that was out of tune with his official position". The Ukrainophiles, in his opinion, also, "made several mistakes in their behavior strategy" [9, 2, p.460]. Before 1873, nationally conscious Ukrainians "even enjoyed some patronage" (the university community and quite many members of the board used to defend Drahomanov from the ministry and insisted on appointing him as an associate professor), but in 18731874 the situation changed dramatically. "The Kyivan Bonapartists took advantage of "the insensible behavior of their ideological opponents and rivals in the social and political field: they began informing on Ukrainophiles, insinuating and inciting the governmental spheres to hostility against Ukrainophiles" [ibid.].

In the end, the mess led to the "shameful", as defined by Yurii Boiko, Ems Ukaz, which was never raised to the status of a law (it "remained unpublished, unmotivated even for the administration"), nor did it have an official title. "The tsar and his helpers were aware of the unlawfulness of their resolutions; though they were not ashamed of their deeds, they still preferred to act quietly, without attracting publicity, without evoking the reaction of the global community" [2, p.340, p. 345]. As regards Mykhailo Drahomanov, whether consciously or not, he acted as an instigator or even a detonator of an anti-Ukrainian "substance" in this despotic tyrannical campaign. As can be seen, he had 
a clear understanding of his involvement in this act of political high-handedness and witches' sabbath among the ruins of Ukrainian independence.

It is obvious that Mykhailo Drahomanov did not act alone in this direction. Behind the Ems Ukaz and attacks on Ukrainian nationhood loomed the gloomy, ominous figure of Mykhailo Yuzefovych," head of the Kyiv Archaeographic Commission. This tradition originated in Ukrainian pre-revolutionary journalism, as stressed by Yurii Boiko, for tactical considerations: "it was important to be able to shift the blame for cultural persecutions onto an irresponsible person in order to make it easier for the government to deviate from the political course chosen" [2, p. 343].

There were serious reasons for holding this opinion. On May 12, Yuzefovych sent a letter to General Potapov, who was escorting Aleksandr II on a visit to Ems, providing additional information, including the following recommendations: "I consider it my duty to be candid and inform Your High Excellency that it is my deep conviction that all the other measures will not settle the matter fully if the Kiev Department of the Geographical Society continues with its current membership" [10, p. 369]. The content of the letter, as noted by the addressee, was presented "for the gracious consideration of His Majesty the Emperor: His Imperial Majesty, having dignified all the suggestions regarding the Kiev Department of the Imperial Geographical Society with his approval, willed to draft a resolution by his own hand, consenting with the opinion of Your Excellency and mine".

Mykhailo Yuzefovych was one of the founders of the South-West Department of the Geographical Society and the first (alongside Bunge, the then rector of the university, and Shulgin, editor of the Kievlianin) to sign the report for the tsar regarding this matter [see: 13, p.93, p.95]. Yet, even organizational steps alone terrified him in view of the likely consequences. For this reason, he was not present at the ceremony of opening the Department. "It is likely that he, together with Shulgin, will dance to the police tune", Pavlo Zhytetskyi assumed [1, p.130]. After seeing the first results of the Department's activities, Yuzefovych became even more alarmed and anxious: he began to suspect it of supporting Ukrainian separatism and blew the whistle. Being against the Department's general course, he soon resigned his membership of the Society and embarked on a campaign aimed at demonization and discreditation. Volodymyr Miiakovskyi assumed that "Potapov, head of the Third Section, owed to Yuzefovych for the information about the Ukrainian movement which was included in the report for the tsar regarding Ukrainophilia in Kyiv". "This report was a prologue to [...] the persecutions of the Ukrainian people in the mid-70s in Kyiv [...]," the researcher noted while describing further concrete steps (in fact - repressive measures) in this regard [13, p.95]. According to the tsar's edict, the government appointed an imperial commission to examine the matter closely and design concrete recommendations and measures. Mykhailo Yuzefovych was not initially there. Determined to act, he wrote an article about his withdrawal from the Geographical Society describing the reasons for his decision, the harmfulness of its activities and the threat they posed for the political regime. Having been prohibited from releasing the article, he described his reasons and arguments in a note entitled $O$ tak nazyvaemom ukrainofilskom dvizhenii (About the So-Called Ukrainophile Movement) and sent it to Petersburgh. For a long time, it remained disregarded, as it seemed, so it was rumored that his denunciations would have no consequences and no investigation would be held into this matter [see: 9, 1, p. 113]. Moreover, Yuzefovych himself was losing hope. Then, suddenly, he received a response at last. The tsar himself informed him about his appointment as a member of the commission on "suppressing Ukrainophile activity". The joy of "the old denunciator" knew no bounds ("he was beside himself with joy") [ibid. p.113]. Thus the matter began to escalate and assumed a new dimension.

Yet, there was no doubt that Mykhailo Yuzefovych was "a person capable of sailing with the wind", and "if a revolution triumphed, he would offer it his services as well". "He betrayed Kostomarov. He informed against the late Sudovshchikov. His denunciations led to dismissing Drahomanov. He is a born spy and denunciator," vividly, with the clarity of a lawyer, and impartially

\footnotetext{
* It was "his denouncements that led to dismissing Drahomanov", banning the Ukrainian word and destroying the basis of the Ukrainophile movement. It should be noted in this regard that in an anonymous article published in Kievskii Telegraf Mykhailo Drahomanov referred to Yuzefovych as "a kind Little Russian activist".
} 
stated Oleksandr Kistiakivskyi [9, 1, p.174]. In other words, he was a scoundrel to the backbone, but hardly an independent player or a creative (let alone charismatic) personality capable of defining the course of history events. Yuzefovych had others behind him - more influential, intelligent and active: university professors Bunge, Vinding, Rennenkampf, Shulgin and co. They have Yuzefovych do what they find too disgusting. "These crafty people do not want to soil themselves with such filth for certain reasons. But for the same reasons, that bastard Yuzefovych uses them in order to achieve his filthy goals" [ibid. p.174].

After Mykhailo Yuzefovych returned from the capital, he was invited to a secret banquet, which the above-mentioned company had organized "far from the public eye" in order to praise and thank him for "his activity yielding successful results" [9, 1, p.214].

However, truth will out. There appeared Oda na prokliatie Yuzefovicha (An Ode to Cursing Yuzeforych), which was submitted for publication. "Undoubtedly, this ode will eternalize the disgraceful name of this denunciator and the chronicles of the Southern Ruthenian nation will preserve his name just like the Roman chronicles preserved the disgraced names of the denunciators of the imperial period [ibid. p.262]* The above-mentioned characters have an important role in the ode since without them Yuzefovych would not have been able to weave that web of intrigue. Needless to say, they took advantage of the results of his "espionage trade": Но Шульгину и Ренненкампфу, / Какую службу сослужил. / Ть трепет их пред «Телеграфом» / Своим доносом разрешил. / От света гласности укрыты, / Теперь они покойны, сыты: / Вкушая гнусные плоды / Доносом добытой победы, / Они, бесстыжие скоть, / Честят тебя в тиши обедом (But to Shulgin and Rennenkampf / You did quite a favor. I Their awe of "The Telegraph" / You dissolved with your denunciation. / They are sheltered from the light of publicity / They are now calm, well-fed: / While relishing the abhorrent fruits of victory / Gained by denunciation, / They, shameless brutes, / Are paying homage to you by a secret dinner) [ibid. p. 262]. That is why he was styled a winner, a triumphant victor.

The actual reason for repressions and persecutions of Ukrainian culture was a surge of the national movement and the self-awareness of the Ukrainians as an independent, mighty and self-sufficient force. The South-West Department of the Russian Geographical Society opened on February 13, 1873. From the very beginning, it gave the impression of being a mature research institution, which could become renowned across the world. The Department owed much to the enthusiasm of Pavlo Chubynskyi, who was first its secretary and from the May of 1875 deputy head; in addition, he headed the famous ethnographic expedition to "The South-West Territory", which resulted in the publication of the findings in seven solid volumes. The Department was explicitly pro-Ukrainian. Among its 22 founding members, the majority (except for 6) were Ukrainians. Overall, before its closure it had 191 active members, 14 associate members and one honorable member [see: 10, p. 342]. It was due to its initiative and active participation that an archaeological congress was held in Kyiv on August 2-16, 1872. It was a triumphant manifestation of Ukrainian culture and science. Needless to say, such achievements alarmed the Russian chauvinistic circles of Kyiv and the local administration. In 1875, the Hromada took over the editorship of the Kievskii Telegraf, which allowed for the possibility of defending its values and interests. Consequently, the government resorted to strict measures intended not only to ban the Ukrainian word and spirituality, but also to fight against "Ukrainian danger" in general.

OLeksandr Kistiakivskyi mentioned one more reason why the Kyivan tetrarchy was hostile to the nationally conscious Ukrainians. In the early 1870s, some of the Ukrainophile activists took part in the elections in Kyiv, became more and more engaged in the city's public events. There was a clear correlation between their activities and the achievements of the Geographical Society. "These two activities of the representatives of the Ukrainophiles alarmed Bunge, Rennenkampf, Shulgin and co. in earnest. They saw that under a normal course of action the Ukrainophiles might, little by little, gain a considerable influence on the city and its affairs. We need to push the Ukrainophiles out of the way; it

\footnotetext{
* The initial version of this work is ascribed to Mykola Verbytskyi (his pseudonym was Mykolaichyk Bilokopytyi), a teacher at a Chernihiv gymnasium, who was transferred to Riazan for his Ukrainophile activities. "The last refinement was done with the cutting tool that belongs to" another Ukrainophile, a teacher of Greek at Gymnasuim No.2 in Kyiv and the founder of a private singing school named after Andrii Yurkevych [9, 1, p. 264-265].
} 
is necessary to prevent them from gaining the influence that will do harm to us, who wish to rule the city and the society" [9, 2, p.460]. The Ukrainization of Kyiv was contrary to the interests of the city's administration and the imperial state institutions. For this reason, they launched a massive campaign aimed at insinuations, provocations, persecutions, and repressions; however, the key players were "staff" members.

One more deeply ingrained belief requires clarification and correction. Mykhailo Drahomanov always attributed his dismissal to the Ukrainophile campaign and his leading role in it. Was it so unambiguous indeed?..

It is true that Mykhailo Yuzefovych sent to Petersburgh some "confidential" information "about the harmful separatist direction" taken by the Geographical Society, and Potapov, head of the Third Section, gave the tsar a report about the nationally conscious Ukrainians from Kyiv. However, Mykhailo Drahomanov's name "was not mentioned" in the denunciations submitted by Potapov or in the note sent by Count Tolstoi to the supervisor of the Kyiv academic district. On top of that - Platon Antonovych separated the two matters firmly and unambiguously: while defending, strange as it might seem, the Ukrainophile movement and, first and foremost, its leader, Volodymyr Antonovych, he was negative about Drahomanov and rejected his demand to be appointed an associate professor at the University of St. Volodymyr. "Of Drahomanov," he replied to the confidential letter from his predecessor and the then friend of the minister, Prince Oleksandr Shyrynskyi-Shykhmatov, "I entered with a special impression, and here I can only repeat myself and say that though in the note about Ukrainophilia described to me by Citizen Dm[itrii] Andr[eevich] (Tolstoi. - R.P.) Drahomanov is not only unidentified among the leaders of the Ukrainophile party but is not mentioned anywhere at all (italics mine. - R.P.) and though his teaching activity cannot be grounds for accusing him of promoting Ukrainophilia, relying only on his article published in the Halychian newspaper Pravda and presented by me to Your Illustrious Highness, I will repeat myself saying that I consider it uncomfortable to keep him among the faculty of Kiev University" [as cited by 13, p.95].

The publication mentioned by Platon Antonovych was the notorious Literatura rosiiska, velykorusska, ukrainska ta halytska (Russian, Great Russian, Ukrainian, and Halychian Literature). Sending the article to Oleksii Suvorin in 1875, Drahomanov noted that he blamed it for his dismissal: "I lost my position despite its pan-Russianism since I do not speak about Tolstoi reverently enough" [8, p.125]. Hence the conclusion suggests itself that Mykhailo Drahomanov's statement in Sankt Peterburgskie Vedomosti caused an outrage by infuriating the reactionary circles and attracting attention to his environment, thus giving a push to launching a frontal attack. It is likely that Attributing his dismissal from the university to Ukrainophilia and explicating a direct interdependence between the two events were done "for technical considerations as it was unfit to appeal to "toast speeches" as a serious motivational factor - even more so because the case of Ukrainian separatism was moving into crazy gear.

The Kyivan intelligentsia did not view Drahomanov as a leading activist of the Ukrainophile campaign. According to a witness' account, such was the general opinion held by both the public and the government administration. In Petersburgh, Moscow, Kyiv it was known that "Drahomanov was a young guy, not really dangerous; and the whole essence of Ukrainophilia is concentrated in the soul of Ant[onovich], whom some are inclined to consider as harboring Polish sympathies as well" [9, 1, p.118]. Thus the latter, on the eve of the collision, resorted to certain preventive measures: he talked to General Pavlov and consulted with Count Uvarov, who found out about the details from "Tolstoi himself". Only after Antonovych had made sure that neither the ministry nor the authorities had anything against him, did he stop worrying; he even continued to head the regional department of the Geographical Society, which "was considered a hotbed of Ukrainophilia" [9, 1, p.118].

After Drahomanov's dismissal from the University of St. Volodymyr, Vitalii Shulgin was said to have pronounced the following sacramental words: "He that cannot hit the horse hits the saddle" [ibid. p.118]. It was rumored that after his talented student and former protégée had emigrated, Shulgin, who was the initiator and driving force of the campaign aimed at maligning and denouncing the nationally conscious Ukrainians, and Mykhailo Drahomanov personally, "used to say [...] that if he had predicted such results, he would have refrained from the polemics with Dr[ahomanov]" [9, 1, p.214]. It is not 
clear whether he said that out of sincerity or the pretentious desire to save some of the face of a former liberalist and Drahomanov's patron.

The latter was considered to be under "a huge influence" of Volodymyr Bonifatiovych. However, that one without doubt "is the chief mechanic in all this activity (the Kyivan Ukrainophiles. $-R$. P.), but not Drahomanov, who only presented the facade of what was preached and desired by Antonovych himself" [9, 1, p. 279-280].

Yet, Mykhailo Drahomanov was dismissed on September 7; on September 19, the order took effect. Drahomanov immediately applied for a foreign passport; and since the procedure was delayed, Oleksandr Dundukov-Korsakov, governor-general of "the South-West Territory", who, according to Ignat Zhytetskyi, projected himself as a liberalist and often "defended Drahomanov" [7, p. 31], personally inquired about his case. "[...] Are there any obstacles to issuing Drahomanov a passport for travelling abroad for research purposes. On my part, there are no obstacles," he inquired of the Third Section by telegraph; and on January 10, 1876, he received a positive answer from Potapov: "Departure abroad is permitted to Professor Drahomanov" [13, p. 96]*.

Yet, there was one more reason why Mykhailo Drahomanov agreed to the mission abroad, thus reshaping the plans of the Hromada to suit his convenience: the desire to break out "into the free air from the heavy atmosphere of Kyiv". This explanation was suggested by Volodymyr Miiakovskyi trying to explicate the dark space of Drahomanov's thoughts and ideas, which he expressed implicitly and vaguely in the letters to Pavlyk and Franko. It follows from the analysis that the "heavy" and "swampy" atmosphere and discomfort were caused by the Ukrainophile "company". Drahomanov wanted to escape from this moral, political, scientific swamp; and his dismissal from the university saved him from being swamped with those circumstances and conditions in which the others faded and died while adjusting to life," Miiakovskyi concluded [13, p. 96].

Drahomanov was not enthusiastic about returning to his homeland from the overseas field trip though the circumstances were favorable. According to his colleagues, the department of general history had a vacancy, so he had a good chance of being appointed a full-time associate professor or even its chair. Thus his colleagues urged him to return as soon as possible, "to strike the iron while it is hot!" [1, p. 125]. However, Mykhailo Drahomanov was taking his time trying to extend his "European independence". He explained to his associates that he needed to finish his doctoral dissertation because without it he could not possibly get the desired position at the university; but in fact he had not even begun his dissertation. Instead, he delved into political and journalistic matters. For two months, he lingered in Zurich, where he established ties with the local radical socialists; and upon return to Kyiv, he created a bitter conflict with the minister of education, Count Tolstoi.

Drahomanov's friends from his Ukrainophile circle were beginning to understand that he was "creating conditions" for his further activity abroad. The first practical step on the road to his objective had to be the launch of "his own publication in Russian and Ukrainian" in Vienna [3, 1, p. 57]. Back then, his plan did not work because he did not have a concrete vision (only a blurred picture), nor did he have enough creative resources to implement it. Now the situation was completely different, and most of its aspects were favorable to his secret intentions. Be that as it may, his dismissal in the fall of 1875 "made him the central figure in all these plans - quite in excess of the expectations of both the community and him himself" [6, p.51].

\section{CONCLUSIONS}

Therefore, Mykhailo Drahomanov suffered for Ukrainophilia. His conflict with the ministry of education was another causative factor in his dismissal from Kyiv University. Yet, Drahomanov also

\footnotetext{
* In one of the letters to Drahomanov abroad, William Berenshtam called Prince Oleksandr Dondukov-Korsakov "a friend of yours, who talked to you frankly" [1, p.57]. Probably, he deserved this definitional characterization not only because he had helped him in the January of 1876 to get a foreign passport without obstacles. Berenshtam knew what he was writing about because he belonged to Drahomanov's closest circle and accompanied ("companioned") his wife and child from Kyiv to Vienna in the late May of 1876. In a later letter to Geneva, he called himself "an old friend" of Mykhailo and Liudmyla the Drahomanovs [1, p. 79].
} 
attributed the conflict to a complex web of interacting national factors such as the struggle for introducing the vernacular in elementary education, though he personally viewed it as a "democratic" Russification of Ukrainians. In the end, Mykhailo Drahomanov unconsidered actions led to the activization of reactionary and anti-Ukrainian forces, the creation of a governmental commission on "suppressing Ukrainophile activity" and the notorious Ems Ukaz. For him personally, the collision ended in political emigration. However, Drahomanov had long before begun to nurture plans to settle abroad and launch "his own" publication. His dismissal from the University of St. Volodymyr actualized his intentions and made him the key figure in the cause of organizing a Ukrainian revolutionary emigration center. In this context, he had to considerably alter his plans and the program of the Ukrainophile campaign.

\section{REFERENCES}

[1] Архів Михайла Арагоманова. Т. 1: Аистування Київської Старої громади з М. Арагомановим (18701895 рр.). Український науковий Інститут, Варшава, 1938.

[Arkhiv Mykhaila Drahomanova. T. 1: Lystuvannia Kyivskoi Staroi hromady z M. Drahomanovym (18701895 rr.). Ukrainskyi naukovyi Instytut, Varshava, 1938.]

[2] Бойко Ю. До стохіття Емського указу. Вибране. Т. ІІІ. Мюнхен, 1981.

[Boiko Yu. Do stolittia Emskoho ukazu. Vybrane. T. III. Miunkhen, 1981.]

[3] Драгоманов М. Аітературно-публіцичтичні праці: у 2 m. Наук. думка, Київ, 1970.

[Drahomanov M. Literaturno-publitsystychni pratsi: $u 2$ t. Nauk. dumka, Kyiv, 1970.]

[4] Драгоманов М. Народні школи на Україні серед життя і письменства в Росії. Вид. "Громада", Geneve; Bale; Lyon: H. Georg, 1877.

[Drahomanov M. Narodni shkoly na Ukraini sered zhyttia i pysmenstva v Rosii. Vyd. "Hromada", Geneve; Bale; Lyon: H. Georg, 1877.]

[5] Драгоманов М. Публіцистика 1860-х років: Публікації в “Санкт-Петербургских ведомостях" (1865-1870). В: Хроніка - 2000: Український культурологічний альманах. Вип. 79. Фонд сприяння розвитку мистецтв, Київ, 2009, 255-334.

[Drahomanov M. Publitsystyka 1860-kh rokiv: Publikatsii v "Sankt-Peterburgskikh vedomostyakh" (1865-1870). V: Khronika - 2000: Ukrainskyi kulturolohichnyi almanakh. Vyp. 79. Fond spryiannia rozvytku mystetstv, Kyiv, 2009, 255-334.]

[6] Грушевський М. 3 починів українського соціялістичного руху. Мих. Арагоманов $і$ женевський социіллістичной гурток. Відень, 1922.

[Hrushevskyi M. Z pochyniv ukrainskoho sotsiialistychnoho rukhu. Mykh. Drahomanov i zhenevskyi sotsiialistychnoi hurtok. Viden, 1922.]

[7] Житецький I. Останній виїзд М. П. Драгоманова за кордон. В: Грушевський М. (Ред.) Україна: Науковий двомісячник українознавства. Київ, 1926, Кн. 2-3 (17), 28-37.

[Zhytetskyi I. Ostannii vyizd M. P. Drahomanova za kordon. V: Hrushevskyi M. (Red.) Ukraina: Naukovyi dvomisiachnyk ukrainoznavstva. Kyiv, 1926, Kn. 2-3 (17), 28-37.]

[8] Абрамович Д.І. 3 листування М. П. Драгоманова з О. С. Суворіним. Київ, 1927, Кн. 4.

[Abramovych D.I. Z lystuvannia M. P. Drahomanova z O. S. Suvorinym. Kyiv, 1927, Kn. 4.]

[9] Кістяківський О. Щоденник (1874-1885): У 2-х. томах. Наукова думка, Київ, 1994.

[Kistiakivskyi O. Shchodennyk (1874-1885): U 2-kh. tomakh. Naukova dumka, Kyiv, 1994.]

[10] Лазаревський Г. Примітки до дистування. В: Архів Михайла Драгоманова. Український науковий Інститут, Варшава, 1938, 341-428.

[Lazarevskyi H. Prymitky do lystuvannia. V: Arkhiv Mykhaila Drahomanova. Ukrainskyi naukovyi Instytut, Varshava, 1938, 341-428.]

[11] Лотоцький О. До світогляду старого українофільства. 3 листування I. Я. Рудченка-Білика з М. П. Арагомановим. 3 минулого, Т. 1. Варшава, 1938. 
[Lototskyi O. Do svitohliadu staroho ukrainofilstva. Z lystuvannia I. Ya. Rudchenka-Bilyka z M. P. Drahomanovym. Z mynuloho, T. 1. Varshava, 1938.]

[12] Михальчук Т. Воспоминания о “Старой Громаде”. Михайло Драгоманов у спогадах. Аибідь, Київ, 2012. [Mykhalchuk T. Vospominaniya o "Staroi Gromade". Mykhailo Drahomanov u spohadakh. Lybid, Kyiv, 2012.]

[13] Міяковський В. Звільнення Драгоманова з Киӥвського університету. Київ, 1926, Кн. 2-3 (17), 90-96.

[Miiakovskyi V. Zvilnennia Drahomanova z Kyivskoho universytetu. Kyiv, 1926, Kn. 2-3 (17), 90-96.]

Address: Roman Pikhmanets, Vasyl Stefanyk Precarpathian National University, 57 Shevchenko St., IvanoFrankivsk, 76025 Ukraine.

E-mail: kaf.lit@ukr.net

Received: June 9, 2020; revised: September 29, 2020.

Піхманець Роман. Звільнення Михайла Драгоманова з університету св. Володимира: текст, підтекст, контекст. Журнал Прикарпатського університету імені Василя Стефаника, 7 (2) (2020), 23-31.

У статті йдеться про мотиви й обставини звільнення Михайла Драгоманова з Київського університету. Детально простежено, зокрема, зав'язку драматичної колізії, зумовленої конфліктом із міністерством народної освіти та особисто з його очільником гр. Толстим. Розгортання акції збіглося 3 репресіями проти революціонерів-народників і піднесенням національно-українського руху. Чвари і суперечки Драгоманова дали підстави антиукраїнським колам прилучити до справи сепаратизм. Його епатажна поведінка спровокувала брудні інсинуації й доноси, внаслідок чого була створена урядова комісія «по пресечению украинофильского движения». Для свідомого українства історія закінчилася ліквідацією Товариства, репресіями супроти його діячів, а відтак і горезвісним Емським указом. Таким чином, Михайло Драгоманов та його авантюрні дії виконали роль збудника i детонатора антиукраїнської кампанії. Особисто ж для нього самого справа закінчилася звільненням 3 університету і драматичними перипетіями політичної еміграції. У статті увагу зосереджено на першій із названих частині цього історичного сюжету та іiі кульмінаційному пункті. Конкретний аналіз засвідчуе існування в ньому «підводних» складників. У науці й суспільній свідомості устадився погляд, згідно з яким головною причиною звільнення Михайла Драгоманова була участь в українофільському русі. Проте ані в надісланій Олександрові II шефом жандармів докладній записці про український сепаратизм, ані в роз'ясненнях міністра освіти кураторові Київського навчального округу його ім'я не згадується. Корекції відбудися трохи пізніше - із якихось загадкових причин. 3'ясовано також, що Михайло Драгоманов ще раніше виношував плани розпочати за кордоном нелегальне видання. Вони синхронізувалися після заборон українського слова із бажаннями дідерів українофільського товариства. Їхні погляди на зміст, ідейні домінанти й конкретні форми діяльності суттєво відрізнялися, але звільнення й еміграція Драгоманова зробили його головним чинником українського закордонно-революційного центру, що неминуче передбачало нові колізій й катаклізми.

Кдючові слова: українофільство, Емський указ, Південно-західне відділення Географічного товариства, закордонне видання, русифікація, провокації, інсинуації. 